\title{
PRO-/ANTIOXIDANT REACTIONS AND NITROGEN OXIDE METABOLISM UNDER SUB-CHRONIC EFFECT OF SUCCINIC ACID DERIVATIVES
}

\author{
I. A. PALAGINA \\ State Institution V. Danilevsky Institute for Endocrine Pathology Problems, \\ National Academy of Medical Science of Ukraine, Kharkiv; \\ e-mail:lab-tox@ukr.net
}

The derivatives of a succinic acid represent active compounds which realize their biological action via the influence on pro-/antioxidant processes and energetic metabolism. We studied the nitrogen oxide metabolism as well as reactions of the proteins and lipids free-radical peroxide oxidation under a sub-chronic effect of anti-diabetically active compounds - succinic acid derivatives and its metabolites. We found that the studied compounds were able to change the intensity of protein- and lipoperoxidation in a liver and blood serum interconnected with changes in the activity of the key antioxidant enzymes. The derivatives of succinic acid proved to inhibit the nitrogen oxide synthase reflected in a decrease in nitrite-and nitrate-anion level in a liver, blood plasma and urine as well as in changes in the oxidation processes in a liver and blood serum. We concluded in stating that the specified changes of pro-/antioxidant and nitrogen oxide homeostasis may serve as assessment criteria of the succinate-containing compounds' biological action.

Ke y word s: succinic acid derivatives, biological action, peroxidation, nitrogen oxide.

$\mathrm{B}$ iological effects of succinic acid derivatives (DSA's) have been extensively studied. This fostered the elaboration on their basis of several original medicines capable of affecting different links of metabolic processes via enhancement of the organism's adaptive capacity, yet are relatively harmless. Succinic acid represents one of the basic metabolites of the tricarboxylic acid (TCA) cycle, and its derivatives (Lymonthar, Reamberine, Mexidol, Mexicore, Yaktone, Sufan etc.) belong to drugs of the metabolic action type that enhance energy metabolism and are capable of correcting the free-radical processes [1, 2]. Among DSA's, researchers have identified compounds with the antioxidant, detoxifying, anti-hypoxic, anti-diabetic, anti-inflammatory, cardio- and hepatoprotective activity [3-6].

It is known that DSA's serve as exogenous donors of an energy substrate, succinate, oxidation of which within the TCA cycle restores $\mathrm{FADH}_{2}$ in structure of the succinate dehydrogenase; however, the actual electron acceptance (accompanied by the ATP synthesis) is accomplished by coenzyme Q in the mitochondrial respiratory chain. The stated compounds are able, at hypoxia conditions, to increase the activity of the succinate-oxidase way of oxidation as the compensatory metabolic flux that normalizes the intracellular pool of ATP and thus facilitates the aerobic energy supply [7]. Our colleagues have previously proved that succinate is a ligand of GPR91 receptor and acts as a signaling molecule that carries the intra- and intercellular interactions, positively influencing the energetic processes in cells. These data indicate an energotropic and anti-hypoxic activity of DSA's interconnected inter alia with their anti-diabetic, cardio-, hepatoand neuroprotective activity $[8,9]$.

A distinctive feature of DSA's covers their antioxidant activity which is manifested under oxidative stress and causes stabilization of the cell membranes and improvement of metabolic processes. It was found that therapeutic doses of sodium succinate and some other DSA's can reduce intensity of the lipid peroxidation (LPO), thus helping to restore the transport of electrons via a part of the respiratory

(C) 2017 Palagina I. A. This is an open-access article distributed under the terms of the Creative Commons Attribution License, which permits unrestricted use, distribution, and reproduction in any medium, provided the original author and source are credited. 
chain links in mitochondria through the shunting of the II complex that transfers electrons from $\mathrm{FADH}_{2}$ to coenzyme Q [10].

Recent research has focused on development of new effective anti-diabetic agents out of the DSA's group which have antioxidant, energy-stimulating properties and are practically non-toxic. One of such promising drugs contains an active ingredient $\beta$-phenylethylamide 2-oxysuccinanyl acid ( $\beta$-PhEAOSAA). It was determined that this compound stimulates regeneration and secretory function of $\beta$-cells of the pancreas, reduces insulin resistance and symptoms of the related metabolic disorders, inhibits development of the diabetic micro- and macro-angiopathies. Molecular mechanisms of its anti-diabetic activity are related to the improvement of bio-energetic processes, oxidative stress suppression in mitochondria as well as to reduction in the non-enzymatic glycosylation [11]. Two potentially active metabolites of the 1st biotransformation phase of $\beta$-PhEA-OSAA, 2-hydroxyphenylsuccinamid (2-HPhSA) and $\beta$-phenylethylsuccinamid $(\beta$-PhESA), were identified, which by their chemical structure also belong to DSA's group and may affect specific and toxic properties of their parent compound.

Estimation of the potential risk of drugs is based on studies of the variety of the most sensitive to their impact links of metabolic homeostasis which hold key positions in mechanisms of toxicity and reflect the level of the organism's adaptive capacity. One of the universal mechanisms of intoxication covers the activation of free radical LPO reactions with disruption of structure and increase of hydrophilicity of cell membranes. This, in turn, leads to mitochondria swelling, inhibition of the respiratory chain enzymes and further on to the separation of the cellular respiration and oxidative phosphorylation. An important part in the tissue and energy metabolism is played by the oxidative modification of proteins (OMP), strengthening of which is considered as one of the earliest and most reliable markers of oxidative stress [12]. The above-mentioned changes are related to the activity of the antioxidant system (AOS) which prevents excessive formation of prooxidants. Also the intensity of peroxidation is affected by the state of the nitrogen oxide (NO) system. Reactive forms of nitrogen $(\mathrm{NO} \bullet-$ nitroxide radical, $\mathrm{ONOO}^{-}$- peroxynitrite) induce oxidative modification of biopolymers that impairs the tissue respiration in mitochondria inner membrane and hydroxylation in microsomes. NO coordinates the interaction of the antioxidant enzymes and is also a highly reactive messenger that easily penetrates through biological membranes and readily reacts with other compounds regulating the free radical and other metabolic transformations [13].

So far the particularities of changes in the free radical reactions and AOS activity under the impact of anti-diabetic agents out of the DSA's group have not been fully elucidated relevant to their doses and duration of exposure.

The aim of this work was to investigate nitrogen oxide metabolism, reactions of proteins and lipids peroxidation in rats under the sub-chronic impact of $\beta$-PhEA-OSAA, 2-HPhSA and $\beta$-PhESA.

\section{Materials and Methods}

Experiments were conducted on 96 white mongrel male rats (190-210 g). The study complied with the General Ethical Principles of Animal Experiments (Ukraine, 2001). Test rats were orally administered 30 -fold of $\beta$-PhEA-OSAA, 2-HPhSA and $\beta$-PhESA in the form of an aqueous emulsion with Twin-80 in doses of 100, 68 and $72 \mathrm{mg} / \mathrm{kg}$ of body weight, respectively. The doses of metabolites were calculated as equimolar to the sub-toxic dose $\left(1 / 100\right.$ half-lethal dose $\left.-\mathrm{DL}_{50}\right)$ of $\beta$-PhEA-OSAA. The control animals received the aqueous emulsion of Twin-80. Animals were decapitated under the light ether anesthesia on the first day after the last administration of the substances. Each test and the control group consisted of 8 animals. For biochemical studies we used such biological substrates as plasma, serum, whole blood, urine, erythrocyte hemolysate, liver homogenate.

State of the LPO processes was assessed by the content of the dienic conjugates (DC), lipid hydroperoxides (LOOH) and thiobarbituric acid reactive substances (TBARS) in serum, whole blood and 10\% liver homogenate. DC content was determined by their extraction from serum or liver with heptaneisopropanol mixture followed by measuring the absorption at $\lambda=233 \mathrm{~nm}$ [14]. LOOH content was registered by the growth of TBARS with introduction the ferrous ions into the incubation medium; the absorption was measured at $\lambda=532 \mathrm{~nm}$ [15]. Determination of TBARS content is based on formation of a colored complex of malonic dialdehyde with thiobarbituric acid, that has a maximum absorption at $\lambda=540 \mathrm{~nm}$ [16]. The content of LPO products was expressed in: $\mu \mathrm{mol}$ per $1 \mathrm{~L}$ in blood serum and nmol per $1 \mathrm{mg}$ of protein in the liver homogenate. 
We assessed a degree of the spontaneous and $\mathrm{Fe}(\mathrm{II})$-induced OMP in blood serum and 5\% liver homogenate. We determined the content of the protein carbonyl fractions $\left(\mathrm{PC}_{356}, \mathrm{PC}_{370}, \mathrm{PC}_{430}, \mathrm{PC}_{530}\right)$ which are the products of interaction between the oxidized amino acid residues of proteins and 2,4-dinitrophenylhydrazine, namely aliphatic aldehydeand ketone-dinitrophenyl-hydrazones of the neutral and basic character. To stimulate OMP we used the Fenton's reagent. Absorption of the OMP products was recorded by a spectrophotometer SF-46 (LOMO, Russia) at $\lambda=356,370,430$ and $530 \mathrm{~nm}$; their content was expressed in absorption units (AbsU) per $1 \mathrm{~g}$ of protein [17].

State of the glutathione system was assessed by the content of reduced glutathione (GSH) in blood using the alloxan method (spectrophotometer SF-46, $\lambda=305 \mathrm{~nm}$, the result measured in $\mathrm{mg}$ per $100 \mathrm{ml}$ ) [18], and by the activity of the glutathione dependent enzymes. We determined glutathione reductase (GR, EC 1.6.4.2) in erythrocytes hemolysate [19], glutathione peroxidase (GPx, EC 1.11.1.9) in erythrocytes hemolysate and 10\% liver homogenate [19], glutathione S-transferase (GST, EC 2.5.1.18) in 10\% liver homogenate [17]. GR activity was indicated by a decrease in incubation medium of the NADPH quantity measured at $37{ }^{\circ} \mathrm{C}$ for $5 \mathrm{~min}$ on spectrophotometer Shimadzu UV-1800 (Japan) at $\lambda=340$ $\mathrm{nm}$ and expressed as $\mu$ mol NADPH in 1 min per $1 \mathrm{~g} \mathrm{Hb}$ (for NADPH $\mathrm{C}_{\mathrm{ME}}=6.22 \cdot 10^{3} \mathrm{M}^{-1} \mathrm{~cm}^{-1}$ ). GPX activity was determined by accumulation of GSSG in incubation medium, and absorption of the samples (without and after incubation) was measured on spectrophotometer SF-46 at $\lambda=260 \mathrm{~nm}$. GPx activity was expressed in $\mu \mathrm{mol}$ in 1 min per $1 \mathrm{~g} \mathrm{Hb}$ or nmol in 1 min per $1 \mathrm{mg}$ protein. GST activity was assessed by the rate of GS-2,4-dinitrobenzene (GS-DNB) formation in reaction of GSH with 1-chlor-2,4-dinitrobenzene, absorption was registered on spectrophotometer UV-1800 at $\lambda=340 \mathrm{~nm}$ for $3 \mathrm{~min}$ at $37{ }^{\circ} \mathrm{C}$. The results were calculated in GS-DNB nmol in $1 \mathrm{~min}$ per $1 \mathrm{mg}$ protein (for GS$\mathrm{DNB} \mathrm{C}_{\mathrm{ME}}=9.6 \cdot 10^{3} \mathrm{M}^{-1} \mathrm{~cm}^{-1}$ ).

We also determined the activity of catalase (EC 1.11.1.6) in serum and $10 \%$ liver homogenate judged by the rate of decomposition of hydrogen peroxide [20]; and the activity of superoxide dismutase (SOD, EC 1.15.1.1) in $10 \%$ liver homogenate judged by a degree of inhibition of quercetin oxidation in presence of tetramethylethylene-diamine [17]. Catalase activity in serum was measured in mkat per 1 liter, in li- ver - in nkat per $1 \mathrm{mg}$ protein, and SOD activity - in arbitrary units per $1 \mathrm{mg}$ protein.

The intensity of nitrogen oxide metabolism was evaluated by the level of nitrites $\left(\mathrm{NO}_{2}^{-}\right)$and nitrates $\left(\mathrm{NO}_{3}^{-}\right)$in the blood plasma, urine and 5\% liver homogenate using spectrophotometric method with the Griess reaction [21]. The concentration of $\mathrm{NO}_{3}^{-}$ and $\mathrm{NO}_{2}^{-}$was expressed in $\mu \mathrm{mol}$ and nmol per 1 liter in plasma and urine, and in nmol and pmol per $1 \mathrm{mg}$ protein in liver homogenate, respectively. Activity of total NO-synthase (NOS, EC 1.14.13.39) was determined in $10 \%$ liver homogenate by the velocity of oxidation of $\mathrm{NADPH}+\mathrm{H}^{+}$[22]. Against these control, in experimental samples we registered a reduction in absorption measured on spectrophotometer UV-1800 at $\lambda=340 \mathrm{~nm}$ for $5 \mathrm{~min}$ at $37^{\circ} \mathrm{C}$. The NOS activity was expressed in nmol of NADPH in 1 min per $1 \mathrm{mg}$ protein. To calculate the enzyme activity and the level of oxidation products we defined the protein content in liver homogenate [23].

The statistical analysis of the results was carried out by using Anova software. Normality of distribution in the sequences was determined using the Shapiro-Wilk (W) criterion. Pair comparison of the experimental groups with the control was performed using the Student's $t$-criterion. Multiple comparison was performed using the Tiuki test. The results are presented as the arithmetic mean and its probable statistical error $(\bar{X} \pm S \bar{x})$. We considered reliable all data at $P<0.05$ and close to the statistically significant at $0.05<P<0.1$. Correlation analysis of indicators was conducted with the Pearson method.

\section{Results and Discussion}

It is known that the antioxidant system involved in utilization of reactive oxygen species (ROS) and peroxide compounds provides regulation of the free radical oxidation and thus, its adequate activity is one of the most important mechanisms of nonspecific cell resistance to the toxic effects of a wide range of xenobiotics, including medicines. The results obtained on the AOS reactions showed that the administration of $\beta$-PhEA-OSAA at a dose of $100 \mathrm{mg} / \mathrm{kg}$ leads to a decrease (by $20 \%$ or more) in the activity of GPx, catalase and GST in rat liver homogenate (Table). It should be noted that GPx and catalase are similar in functionality, having the ability to restore peroxides radicals to their inactive status. GPx catalyzes the reaction of detoxification of organic hydroperoxides, as well as, can destroy $\mathrm{H}_{2} \mathrm{O}_{2}$ at low concentrations. Catalase performs a key 
function in protecting cells from high concentrations of $\mathrm{H}_{2} \mathrm{O}_{2}$ and catalyzes the oxidation of low molecular weight alcohols and nitrites. GST, which activity is also reduced in the liver, belongs to enzymes of phase II detoxification that neutralizes toxic metabolites, including LPO products by their conjugation with glutathione.

The impact of $\beta$-PhESA at a dose of $72 \mathrm{mg} / \mathrm{kg}$ was proved to reduce the GPx activity in the liver and of 2-HPhSA (68 mg/kg), in erythrocytes, but these changes were accompanied by a compensatory increase in catalase activity in serum, and in the case of $\beta$-PhESA also in the liver. Under the introduction of $\beta$-PhESA we registered almost two-fold increase in the activity of GR in erythrocytes. This affects the increase in content of GSH in the blood, but more moderate in view of the likely loss of this most important resource of the antioxidant defense, inter alia in the processes of neutralization of free radical oxidation metabolites (Table).

Therefore, the studied DSA's cause a decrease in the activity of GPx, and $\beta$-PhEA-OSAA, also of catalase and GST. In the case of $\beta$-PhESA and 2-HPhSA impact, we observed a compensatory increase in the activity of catalase and GR, the functioning of which is closely interrelated with the level of GPx activity. In turn, the activation of these compensatory processes reduces the likelihood of damage to membranes of the liver cells and erythrocytes due to attack of the free radicals and peroxides on the lipid and protein molecules.

Antioxidant enzymes are rather adaptive, their activity is largely regulated by concentration of the lipo-, protein-peroxidation products and ROS. We found that the introduction of $\beta$-PhEA-OSAA reduced the DC level in the liver by $23 \%$ and the TBARS level by $35 \%$. Normally, these changes can be related to spending of the AOS reserves aimed to inhibit free radical oxidation. In turn, the reduction in peroxidation products content brings on a decrease in activity of antioxidant enzymes in the liver. However, at the level of the whole organism, under the impact of all studied compounds we registered signs of activation of LPO comprising various stages reactions of the process. The most pronounced rise in the LPO intensity and increased activity of antioxidant enzymes in blood was seen under $\beta$-PhESA introduction (Table).

Under the influence of $\beta$-PhEA-OSAA, in the liver the changes of LPO are synchronized with a significant increase in the spontaneous and Fe(II)- induced levels of $\mathrm{PC}_{530}$ - aliphatic ketone-dinitrophenylhydrazones (KDNPhH) of the basic character. These PC lose their functional activity in the process of the protein molecules aggregation. We registered an increase in the intensity of $\mathrm{Fe}(\mathrm{II})$-induced OMP at 356 and $370 \mathrm{~nm}$, which in percentage terms was lower than the one at $530 \mathrm{~nm}$. Here we found the stimulation of the protein-synthesizing function of the liver that indicate a possibility of a compensatory restoration of proteins in tissues. After the administration of $\beta$-PhEA-OSAA the total protein content in the rat's liver increased up to $30.4 \pm 0.7 \mathrm{mg} / \mathrm{ml}$ compared to $22.9 \pm 1.3 \mathrm{mg} / \mathrm{ml}$ in the control group $(P<0.05) . \beta$-PhESA in the liver also causes an increase in the activity of spontaneous OMP that comprises all studied protein carbonyl fractions but most marked is for $\mathrm{PC}_{530}$ and $\mathrm{PC}_{430}$, i.e. for the modified proteins on basic amino acid residues. Under 2-HPhSA impact, the spontaneous level of $\mathrm{PC}_{530}$ and $\mathrm{PC}_{430}$ decreases slightly (Table).

Thus, the use of $\beta$-PhEA-OSAA and $\beta$-PhESA leads to amplification of the OMP and, in turn, the formation of an excess of PC can affect the reactions of LPO, in particular reducing its intensity, as in the case of $\beta$-PhEA-OSAA (a manifestation of the secondary "antioxidant effect"). It is known that the advantage of overall KDNPhH (as markers of the protein aggregation), most of which are formed in the later stages of the oxidative stress, over the aldehyde-dinitrophenylhydrazones $(\mathrm{ADNPhH})$ as products of the proteins fragmentation, indicates a possibility of advancing the oxidative damage in cells [12]. Such changes we recorded under the effect of the parent compound, and its metabolite $\beta$-PhESA equally stimulated the formation of $\mathrm{ADNPhH}$ and $\mathrm{KDNPhH}$. Moreover, both compounds proved to increase in the liver the content of mainly basic PC. It is known that the content of these PC fractions usually increases in diabetes mellitus and metabolic syndrome [24], and can vary due to the influence of the anti-diabetic drugs depending on dose administration. Therefore we concluded that a significant increase in the content of basic PC under the influence of these compounds may serve as a biological criterion of their action in subtoxic doses.

$\beta$-PhEA-OSAA causes activation of both spontaneous and induced OMP. The second parameter indicates the presence of the additional reserves for the oxidation, and the tension of the adaptive capabilities of cells in order to reduce OMP intensity. Induced OMP reveals not only the modifications of the amino 
Parameters of AOS, LPO, OMP and NO metabolism in rats under impact of $\beta$-PhEA-OSAA and its metabolites

\begin{tabular}{|c|c|c|c|c|c|c|}
\hline Parameter & Control 1 & $\begin{array}{l}\beta \text {-PhEA- } \\
\text { OSAA }\end{array}$ & Control 2 & 2-HPhSA & Control 3 & $\beta$-PhESA \\
\hline GSH, mg/100 ml & $21.2 \pm 2.8$ & $17.5 \pm 1.5$ & $14.7 \pm 1.9$ & $14.5 \pm 1.3$ & $27.2 \pm 1.9$ & $\begin{array}{c}38.2 \pm 5.1 \\
P=0.063\end{array}$ \\
\hline $\begin{array}{l}\text { GR of erythrocytes, } \\
\mu \mathrm{mol} \mathrm{NADPH} / \\
\mathrm{min} \cdot \mathrm{g} \mathrm{Hb}\end{array}$ & $4.68 \pm 0.61$ & $6.01 \pm 0.76$ & $2.61 \pm 0.21$ & $2.56 \pm 0.25$ & $1.98 \pm 0.26$ & $\begin{array}{l}4.05 \pm 0.66 \\
P=0.024\end{array}$ \\
\hline $\begin{array}{l}\text { GPx of erythrocytes, } \\
\mu \mathrm{mol} \text { GSSG/min.g Hb }\end{array}$ & $298.6 \pm 25.7$ & $333.9 \pm 30.8$ & $196.3 \pm 21.8$ & $\begin{array}{c}139.0 \pm 9.0 \\
P=0.035\end{array}$ & $174.7 \pm 16.0$ & $169.0 \pm 14.0$ \\
\hline $\begin{array}{l}\text { GPx of liver, nmol } \\
\text { GSSG/min·mg protein }\end{array}$ & $143.9 \pm 6.4$ & $\begin{array}{c}113.9 \pm 1.7 \\
\mathrm{P}=0.0001\end{array}$ & $164.1 \pm 27.9$ & $153.6 \pm 21.9$ & $102.0 \pm 8.8$ & $\begin{array}{l}79.0 \pm 7.7 \\
\mathrm{P}=0.074\end{array}$ \\
\hline $\begin{array}{l}\text { GST of liver, } \\
\text { nmol GS-DNB/ } \\
\text { min·mg protein }\end{array}$ & $45.6 \pm 3.8$ & $\begin{array}{c}36.70 \pm 0.66 \\
P=0.028\end{array}$ & $57.8 \pm 7.6$ & $71,9 \pm 8,0$ & $78.5 \pm 8.4$ & $88.8 \pm 10.4$ \\
\hline $\begin{array}{l}\text { Catalase: of serum, } \\
\text { mkat } \mathrm{H}_{2} \mathrm{O}_{2} / \mathrm{l} \text {; of liver, } \\
\text { nkat } \mathrm{H}_{2} \mathrm{O}_{2} / \mathrm{mg} \text { protein }\end{array}$ & $\begin{array}{l}1.00 \pm 0.03 \\
4.68 \pm 0.30\end{array}$ & $\begin{array}{l}0.94 \pm 0.02 \\
3.58 \pm 0.09 \\
P=0.004\end{array}$ & $\begin{array}{l}1.02 \pm 0.09 \\
3.79 \pm 0.63\end{array}$ & $\begin{array}{l}1.38 \pm 0.03 \\
P=0.001 \\
3.03 \pm 0.35\end{array}$ & $\begin{array}{l}0.96 \pm 0.07 \\
3.41 \pm 0.20\end{array}$ & $\begin{array}{l}1.24 \pm 0.08 \\
P=0.024 \\
4.15 \pm 0.22 \\
P=0.029\end{array}$ \\
\hline $\begin{array}{l}\text { SOD of liver, arbit. } \\
\text { units/min·mg protein }\end{array}$ & $284.2 \pm 25.4$ & $274.8 \pm 17.5$ & $377.7 \pm 81.8$ & $460.9 \pm 73.8$ & $427.6 \pm 50.2$ & $361.8 \pm 36.3$ \\
\hline $\begin{array}{l}\text { DC: serum, } \mu \mathrm{mol} / 1 \\
\text { liver, } \mathrm{nmol} / \mathrm{mg} \text { protein }\end{array}$ & $\begin{array}{l}3.53 \pm 0.32 \\
0.22 \pm 0.01\end{array}$ & $\begin{array}{l}3.74 \pm 0.21 \\
0.17 \pm 0.01 \\
P=0.026\end{array}$ & $\begin{array}{l}3.64 \pm 0.13 \\
0.18 \pm 0.02\end{array}$ & $\begin{array}{l}5.12 \pm 0.46 \\
P=0.008 \\
0.19 \pm 0.03\end{array}$ & $\begin{array}{r}2.48 \pm 0.14 \\
0.14 \pm 0.02\end{array}$ & $\begin{array}{r}2.35 \pm 0.16 \\
0.13 \pm 0.01\end{array}$ \\
\hline $\begin{array}{l}\text { TBARS: blood, } \mu \mathrm{mol} / 1 \\
\text { liver, nmol/mg protein }\end{array}$ & $\begin{array}{l}0.98 \pm 0.16 \\
0.31 \pm 0.03\end{array}$ & $\begin{array}{l}0.80 \pm 0.05 \\
0.20 \pm 0.02 \\
P=0.009\end{array}$ & $\begin{array}{l}1.07 \pm 0.06 \\
0.26 \pm 0.03\end{array}$ & $\begin{array}{l}1.16 \pm 0.05 \\
0.39 \pm 0.07\end{array}$ & $\begin{array}{l}0.92 \pm 0.11 \\
0.43 \pm 0.03\end{array}$ & $\begin{array}{c}1.28 \pm 0.06 \\
P=0.013 \\
0.52 \pm 0.03 \\
P=0.067\end{array}$ \\
\hline $\begin{array}{l}\text { LOOH: serum, } \mu \text { mol/1 } \\
\text { liver, } n m o l / m g \text { protein }\end{array}$ & $\begin{array}{l}3.53 \pm 0.29 \\
0.53 \pm 0.05\end{array}$ & $\begin{array}{l}5.16 \pm 0.56 \\
P=0.021 \\
0.53 \pm 0.04\end{array}$ & $\begin{array}{l}5.02 \pm 0.59 \\
0.38 \pm 0.06\end{array}$ & $\begin{array}{l}5.92 \pm 0.44 \\
0.55 \pm 0.10\end{array}$ & $\begin{array}{l}3.08 \pm 0.17 \\
0.53 \pm 0.05\end{array}$ & $\begin{array}{l}4.37 \pm 0.35 \\
P=0.008 \\
0.48 \pm 0.05\end{array}$ \\
\hline $\begin{array}{l}\text { Spontaneous OMP } \\
\text { of serum, AbsU/g } \\
\text { protein: } \text { PC }_{356}\end{array}$ & $33.6 \pm 1.3$ & $\begin{array}{l}39.3 \pm 2.3 \\
\mathrm{P}=0.047\end{array}$ & $29.0 \pm 1.8$ & $28.6 \pm 1.4$ & $23.1 \pm 3.1$ & $21.0 \pm 2.2$ \\
\hline $\mathrm{PC}_{370}$ & $32.0 \pm 1.1$ & $\begin{array}{l}38.8 \pm 2.3 \\
\mathrm{P}=0,019\end{array}$ & $25.8 \pm 1.0$ & $\begin{array}{l}30.6 \pm 2.1 \\
\mathrm{P}=0.068\end{array}$ & $23.0 \pm 1.9$ & $22.2 \pm 2.1$ \\
\hline $\mathrm{PC}_{430}$ & $13.6 \pm 0.7$ & $\begin{array}{l}19.0 \pm 1.2 \\
\mathrm{P}=0.001\end{array}$ & $11.7 \pm 0.8$ & $\begin{array}{l}14.6 \pm 1.1 \\
\mathrm{P}=0.053\end{array}$ & $13.8 \pm 2.0$ & $12.0 \pm 1.2$ \\
\hline $\mathrm{PC}_{530}$ & $1.57 \pm 0.15$ & $\begin{array}{l}2.64 \pm 0.10 \\
P=0.0001\end{array}$ & $1.74 \pm 0.15$ & $1.79 \pm 0.31$ & $2.20 \pm 0.24$ & $1.62 \pm 0.24$ \\
\hline $\begin{array}{l}\mathrm{Fe}^{2+} \text {-induced OMP } \\
\text { of serum, } \mathrm{AbsU} / \mathrm{g} \\
\text { protein: } \mathrm{PC}_{356}\end{array}$ & $71.3 \pm 2.0$ & $68.0 \pm 1.2$ & $49.6 \pm 3.9$ & $49.4 \pm 1.1$ & $66.2 \pm 2.9$ & $60.0 \pm 2.2$ \\
\hline $\mathrm{PC}_{370}$ & $70.6 \pm 1.7$ & $\begin{array}{c}66.9 \pm 1.2 \\
\mathrm{P}=0.098\end{array}$ & $51.3 \pm 3.5$ & $52.7 \pm 0.8$ & $73.6 \pm 3.0$ & $70.0 \pm 3.6$ \\
\hline $\mathrm{PC}_{430}$ & $31.4 \pm 0.7$ & $\begin{array}{c}28.7 \pm 0.6 \\
P=0.016\end{array}$ & $28.5 \pm 1.8$ & $\begin{array}{l}32.5 \pm 1,2 \\
\mathrm{P}=0,081\end{array}$ & $44.1 \pm 1.9$ & $44.5 \pm 2.2$ \\
\hline $\mathrm{PC}_{530}$ & $2.63 \pm 0.28$ & $2.23 \pm 0.19$ & $3.05 \pm 0.36$ & $\begin{array}{l}4.64 \pm 0.21 \\
P=0.002\end{array}$ & $6.69 \pm 0.92$ & $\begin{array}{c}4.65 \pm 0.49 \\
P=0.063\end{array}$ \\
\hline
\end{tabular}




\section{Table (Continuation)}

\begin{tabular}{|c|c|c|c|c|c|c|}
\hline Parameter & Control 1 & $\begin{array}{c}\beta \text {-PhEA- } \\
\text { OSAA }\end{array}$ & Control 2 & 2-HPhSA & Control 3 & $\beta$-PhESA \\
\hline $\begin{array}{l}\text { Spontaneous OMP } \\
\text { of liver, } \mathrm{AbsU/g} \\
\text { protein: } \mathrm{PC}_{356}\end{array}$ & $111.1 \pm 7.2$ & $113.2 \pm 6.1$ & $102.0 \pm 10.7$ & $81.3 \pm 9.0$ & $114.6 \pm 4.9$ & $\begin{array}{c}145.4 \pm 13.5 \\
\mathrm{P}=0.063\end{array}$ \\
\hline $\mathrm{PC}_{370}$ & $109.8 \pm 8.2$ & $112.8 \pm 5.7$ & $100.1 \pm 10.5$ & $80.7 \pm 8.6$ & $108.5 \pm 4.9$ & $\begin{array}{c}135.2 \pm 11.6 \\
P=0.065\end{array}$ \\
\hline $\mathrm{PC}_{430}$ & $35.0 \pm 3.2$ & $30.4 \pm 4.3$ & $47.9 \pm 4.4$ & $\begin{array}{c}28.8 \pm 3.1 \\
\mathrm{P}=0.003\end{array}$ & $42.7 \pm 3.0$ & $\begin{array}{l}66.3 \pm 2.8 \\
\mathrm{P}=0.0001\end{array}$ \\
\hline $\mathrm{PC}_{530}$ & $11.5 \pm 0.7$ & $\begin{array}{l}19.0 \pm 1.3 \\
\mathrm{P}=0.0001\end{array}$ & $9.1 \pm 0.5$ & $\begin{array}{l}5.2 \pm 0.7 \\
\mathrm{P}=0.002\end{array}$ & $8.31 \pm 0.72$ & $\begin{array}{c}13.6 \pm 2.1 \\
\mathrm{P}=0.033\end{array}$ \\
\hline $\begin{array}{l}\mathrm{Fe}^{2+} \text {-induced OMP } \\
\text { of liver, } \mathrm{AbsU/g} \\
\text { protein: } \mathrm{PC}_{356}\end{array}$ & $216.4 \pm 3.9$ & $\begin{array}{c}239.0 \pm 4.0 \\
P=0.002\end{array}$ & $180.0 \pm 22.4$ & $228.0 \pm 39.0$ & $251.6 \pm 18.7$ & $242.0 \pm 18.5$ \\
\hline $\mathrm{PC}_{370}$ & $214.9 \pm 4.4$ & $\begin{array}{c}233.2 \pm 6.6 \\
P=0.044\end{array}$ & $192.6 \pm 27.4$ & $234.3 \pm 39.2$ & $252.0 \pm 17.9$ & $247.2 \pm 17.5$ \\
\hline $\mathrm{PC}_{430}$ & $120.9 \pm 3.0$ & $125.7 \pm 7.5$ & $146.5 \pm 23.3$ & $162.2 \pm 26.2$ & $162.6 \pm 10.7$ & $169.8 \pm 11.1$ \\
\hline $\mathrm{PC}_{530}$ & $28.7 \pm 3.2$ & $\begin{array}{l}42.5 \pm 4.0 \\
\mathrm{P}=0.02\end{array}$ & $25.8 \pm 4.2$ & $36.7 \pm 6.5$ & $24.4 \pm 2.6$ & $23.8 \pm 3.9$ \\
\hline $\begin{array}{l}\mathrm{NO}_{2}^{-} \text {of liver, } \\
\mathrm{pmol} / \mathrm{mg} \text { protein }\end{array}$ & $607 \pm 40$ & $\begin{array}{l}402 \pm 47 \\
\mathrm{P}=0.005\end{array}$ & $350 \pm 26$ & $295 \pm 23$ & $407 \pm 28$ & $\begin{array}{c}334 \pm 32 \\
\mathrm{P}=0.112\end{array}$ \\
\hline $\begin{array}{l}\mathrm{NO}_{3}^{-} \text {of liver, } \\
\mathrm{nmol} / \mathrm{mg} \text { protein }\end{array}$ & $58.7 \pm 3.2$ & $\begin{array}{l}41.5 \pm 4.5 \\
P=0.008\end{array}$ & $51.8 \pm 3.7$ & $40.0 \pm 6.5$ & $60.1 \pm 4.1$ & $\begin{array}{c}50.0 \pm 4.6 \\
\mathrm{P}=0.125\end{array}$ \\
\hline $\begin{array}{l}\text { NOS of liver, nmol } \\
\text { NADPH/min'mg } \\
\text { protein }\end{array}$ & $2.51 \pm 0.34$ & $\begin{array}{l}1.42 \pm 0.17 \\
\mathrm{P}=0.02\end{array}$ & $3.73 \pm 0.34$ & $3.09 \pm 0.37$ & $5.15 \pm 0.75$ & $\begin{array}{c}3.48 \pm 0.43 \\
\mathrm{P}=0.087\end{array}$ \\
\hline
\end{tabular}

Note. Deviation is significant compared to relative control at $P<0.05$; deviation is close to significant at $0.05<P<0.1$

acid residues of proteins, but also the conformation of the molecule and changes in the state of protein environment. The accumulation of OMP products may be associated with a reduced activity of the proteasic systems in cells [25].

Changes in the blood serum OMP intensity reflect the general orientation of free radical reactions in the whole organism. Under the impact of the parent compound, in blood serum, increases in the content of all studied products of spontaneous OMP, but more of all the basic PC, were observed. The content of $\mathrm{KDNPhH}$ grows a bit more intensively than ADNPhH content; it tells about the prevailing increase in aggregation of protein molecules which serves as a late marker of oxidative stress. However, $\beta$-PhEA-OSAA and $\beta$-PhESA proved to decrease the activity of $\mathrm{Fe}(\mathrm{II})$-induced protein degradation that indicates a decrease of the backup substrate for the OMP. 2-HPhSA caused an increase in the spontaneous OMP level (but to a lesser extent than the parent compound) and also of the induced OMP which is mainly concerned with $\mathrm{PC}_{530}$ (Table). As a result of the $\beta$-PhEA-OSAA and 2-HPhSA action, in serum the content of the total protein increased up to $77.0 \pm 2.0 \mathrm{~g} / \mathrm{l}$ compared to $70.7 \pm 1.5 \mathrm{~g} / \mathrm{l}$ in the control group $(P<0.05)$ and up to $72.0 \pm 0.9 \mathrm{~g} / \mathrm{l}$ compared to $69.1 \pm 0.6 \mathrm{~g} / \mathrm{l}$ in the control group $(0.05<P<0.1)$, respectively. These changes can be regarded as adaptive reactions aimed to restore the protein composition of the blood.

Thus, under the impact of succinate-containing compounds in tested doses we found an increase of the LPO products and/or OMP in serum which may indicate some increase in the activity of free radical oxidation in the whole organism. It is known that these changes gain may affect the membrane structure of cells and organelles (including mitochondria) and the activity of enzymes associated with them. Previous studies have established that $\beta$-PhEAOSAA at a dose of $100 \mathrm{mg} / \mathrm{kg}$ inhibits succinate de- 
hydrogenase and stimulates cytochrome-c-oxidase in the liver mitochondria against the background of the activation of microsomal oxidation [26].

Stimulated by the introduction of $\beta$-PhEAOSAA and $\beta$-PhESA increase in the content of PC in liver on the background of the reducing activity of the anti-peroxide enzymes (GPx for both compounds, catalase for $\beta$-PhEA-OSAA) may possibly be caused by inhibition of NO metabolism. This is characterized by a 1.8- and 1.5-fold decrease in the activity of NOS as well as by a drop in $\mathrm{NO}_{2}{ }^{-}$and $\mathrm{NO}_{3}{ }^{-}$content (by 34 and $29 \%$ for the first compound and 18 and $17 \%$ for the second) (Table). The content of the NO metabolites in liver declines slower than the NOS activity, evidently due to the possibility of their partial reduction in nitrite-/ nitrate-reductase reactions of the NO metabolism cycle or through other compensatory mechanisms [27].

Under $\beta$-PhEA-OSAA impact we registered a decrease in the content of $\mathrm{NO}_{2}^{-}$and $\mathrm{NO}_{3}{ }^{-}$by 41 and $34 \%$ in plasma and by 56 and $42 \%$ in urine, respectively. The same direction of changes of parameters was caused by 2 -HPhSA and $\beta$-PhESA but they were more pronounced compared to $\beta$-PhEA-OSAA in the first case and less manifested in the second (Fig. 1, 2, 3 , 4). These changes, to some extent, are stipulated by inhibition of the constitutive NOS of liver registered under $\beta$-PhEA-OSAA and $\beta$-PhESA influence, and probably by NOS of the vascular endothelium and platelets. Highly reactive NO can interact with the thiol- and gem-containing compounds with formation of more stable transport forms and sub-

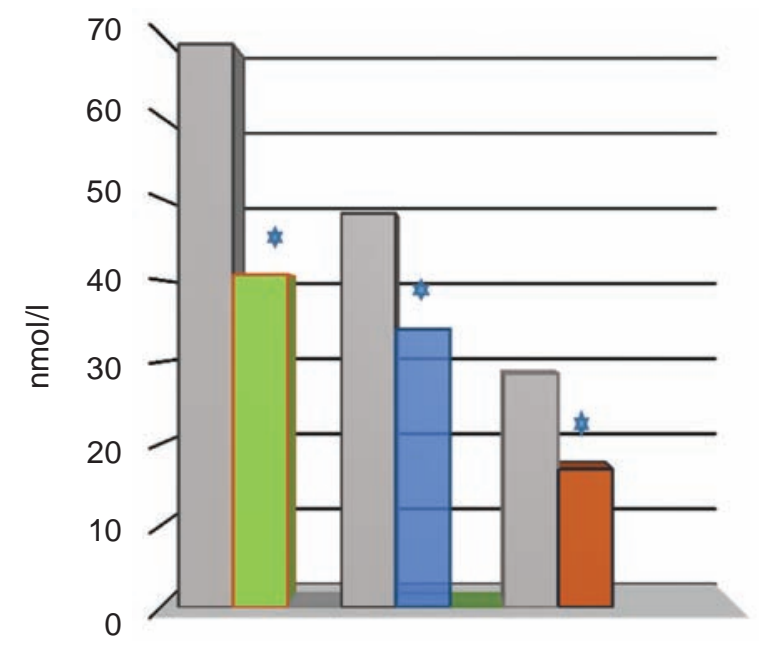

Fig. 1. Content of nitrite-anion in the rat blood plasma. Here, in Fig. 2-4: $\square-$ control, $\square-2-H P h S A$, $\square-\beta$-PhESA, $\square-\beta$-PhEA-OSAA, $* P<0.05$

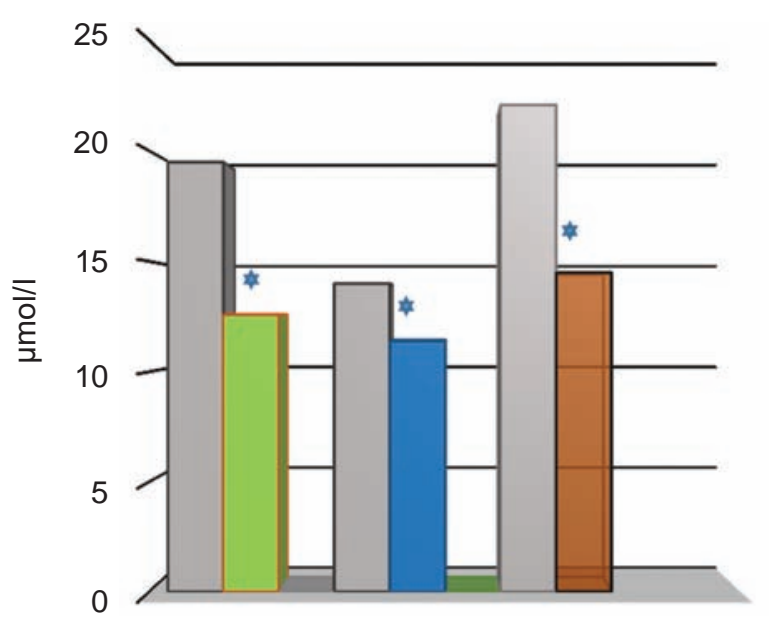

Fig. 2. Content of nitrate-anion in the rat blood plasma

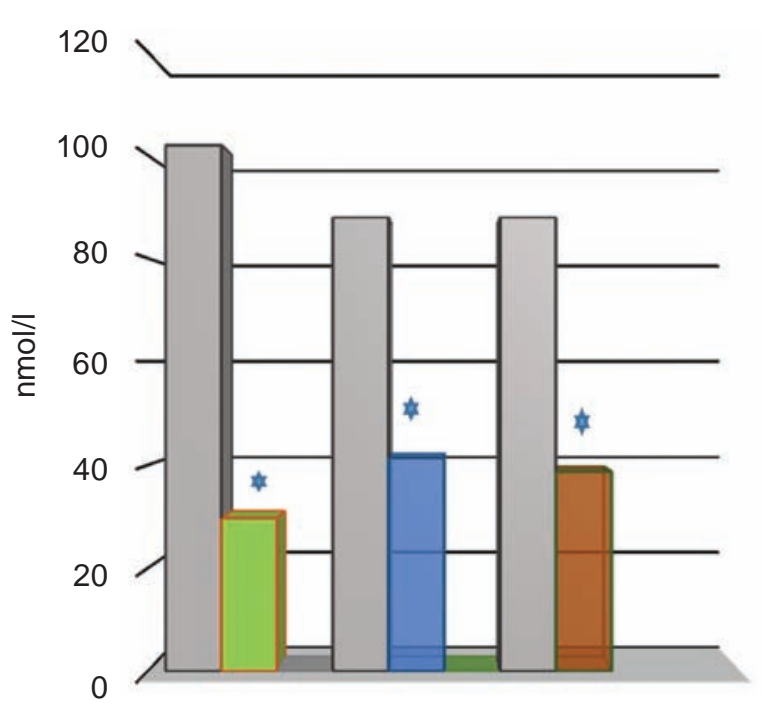

Fig. 3. Content of nitrite-anion in the rat urine

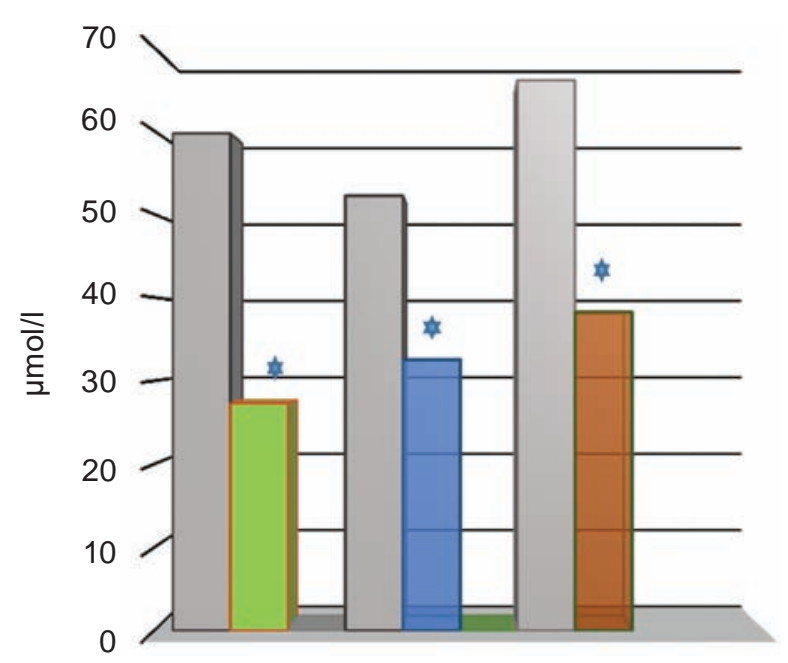

Fig. 4. Content of nitrate-anion in the rat urine 
sequent deposition in tissues that can affect the NO metabolites content [13].

We found that the influence of all three succinic acid derivatives reduced the content of $\mathrm{NO}_{2}{ }^{-}$more than of $\mathrm{NO}_{3}{ }^{-}$in blood plasma, and besides, both parameters reduce more in urine compared with these values in blood plasma. It is known that the $\mathrm{NO}_{2}{ }^{-}$ content in blood plasma largely depends on the activity of endothelial NOS and is proportional to the total endothelial NO synthesis, unlike other NO metabolites. $\mathrm{NO}_{2}^{-}$is more reactive than $\mathrm{NO}_{3}^{-}$, and therefore is involved in a wide range of metabolic transformations that also affects a decrease in its content. The content of $\mathrm{NO}_{3}^{-}$, on the contrary, only partially depends on the activity of the NOS-dependent ways of its metabolism. Some of it can be also formed with the oxidation of peroxynitrite [28].

However, the content of $\mathrm{NO}_{2}{ }^{-}$and $\mathrm{NO}_{3}{ }^{-}$- in extra-cellular fluid may be influenced not only by the intensity of NO production but also by the rate of renal clearance [29]. In our studies, inhibition of the rate of urinary $\mathrm{NO}_{2}^{-}$and $\mathrm{NO}_{3}{ }^{-}$excretion was probably connected with the strengthening of their tubular re-absorption in the proximal segment of nephron. Such kind of activity which is associated with activation of intra-renal mechanisms of NO-NOS system regulation, was more expressed under the impact of 2-HPhSA compared with $\beta$-PhEA-OSAA and $\beta$-PhESA.

We found that under the introduction of succinamides the slowing or containment in intensification of peroxidation correlates with the degree of adaptive reduction in the $\mathrm{NO}_{2}^{-}$content in plasma that, to a certain extent, regulated by the state of NO-synthase/nitrite-reductase system. In turn, the reduction in NO production may be connected to inhibition of the endothelial NOS expression by the ROS.

Therefore, the succinate-containing compounds in tested doses affect the state of the oxidative homeostasis by modifying the intensity of LPO and OMP, in conjunction with the decrease in activity of GPx and NO metabolism in the organism. It is known that the increased degradation of proteins and lipids may be a consequence of ROS generation due to the activation of certain links in respiratory chain of mitochondria. In particular $\beta$-PhEA-OSAA is able to stimulate cytochrome-c-oxidase, that is, to influence the final stage of electrons transfer. The action of succinamides can be also realized at the expense of their substrate activity as far as they bear a succinate in their structure. As to $\beta$-PhEA-OSAA and 2-HPhSA, they affect the mitochondrial succinate-dehydrogenase that supplies $\mathrm{FADH}_{2}$ into the respiratory chain of mitochondria [26].

For a systemic reflection of interactions between the OMP, LPO, AOS and NO metabolism parameters which have been changed under the succinic acid derivatives impact, we applied methods of correlation analysis. The influence of $\beta$-PhEAOSAA showed the inverse correlation between the increase of the spontaneous $\mathrm{PC}_{530}$ level as well as $\mathrm{LOOH}$ content in serum and decreased DC content in liver $(r=-0.7 ;-0.96)$. We proved that the activation of LPO in serum and inhibition of its primary reactions in liver is clearly associated with a lower content of $\mathrm{NO}_{2}{ }^{-}$and $\mathrm{NO}_{3}{ }^{-}$in the liver $(r=-0.93$, $-0.89 ; 0.85,0.79$ ). The LPO inhibition in liver is also interconnected with the reduction in hepatic catalase activity $(r=0.93)$, which, in turn, correlates with the decrease in $\mathrm{NO}_{2}{ }^{-}$and $\mathrm{NO}_{3}{ }^{-}$content in blood plasma $(r=0.71,0.7)$ and with an increased spontaneous OMP530 in blood serum $(r=-0.75)$. The decrease in the activity of GPx and GST in liver largely depends on intensification of the spontaneous and induced OMP $(r=-0.78 \div 1.0)$. We set a high direct correlations of the NOS activity with the decrease of $\mathrm{NO}_{2}{ }^{-}$and $\mathrm{NO}_{3}{ }^{-}$content in urine $(r=0.92 ; 0.92)$, intensification of the spontaneous $\mathrm{OMP}_{356}$ and $\mathrm{OMP}_{370}$ of serum $(r=-0.81 ;-0.8)$, and induced $\mathrm{OMP}_{356}$ and $\mathrm{OMP}_{370}$ of liver $(r=-0.89 ;-0.88)$.

Under 2-HPhSA impact we found a direct correlation between increases in the $\mathrm{Fe}(\mathrm{II})$-induced $\mathrm{PC}_{530}$ and DC contents in blood serum $(r=0.94)$. Intensification of the spontaneous $\mathrm{OMP}_{370}$ and $\mathrm{OMP}_{430}$ in serum significantly affects the decrease in the $\mathrm{NO}_{2}{ }^{-}$and $\mathrm{NO}_{3}{ }^{-}$content in liver $(r=-0.71,-0.7 ;-0.8$, -0.75). In the liver, on the contrary, we registered a decrease in the spontaneous level of $\mathrm{PC}_{430}$ and $\mathrm{PC}_{530}$, the first of which is associated with an increased activity of serum catalase $(r=-0.83)$ and the second largely depends on the decrease in the $\mathrm{NO}_{2}{ }^{-}$and $\mathrm{NO}_{3}{ }^{-}$content in blood plasma $(r=0.75,0.75)$. The activity of GPx of erythrocytes and NOS of liver is well correlated with each other $(r=0.96)$ and with the decrease in the $\mathrm{NO}_{2}{ }^{-}$and $\mathrm{NO}_{3}{ }^{-}$content in blood plasma $(r=0.9,0.9 ; 0.89,0.89)$.

The influence of $\beta$-PhESA was characterized by the inverse correlation between intensification of the spontaneous OMP in liver and the content of NO metabolites. The $\mathrm{PC}_{430}$ and $\mathrm{PC}_{530}$ correlated with $\mathrm{NO}_{2}{ }^{-}$and $\mathrm{NO}_{3}{ }^{-}$in liver $(r=-0.73$ and -0.73 ; 
-0.7 and -0.7), $\mathrm{PC}_{430}$ with $\mathrm{NO}_{2}{ }^{-}$and $\mathrm{NO}_{3}{ }^{-}$of blood plasma ( $r=-0.9$ and -0.9$), \mathrm{PC}_{530}$ with $\mathrm{NO}_{2}^{-}$and $\mathrm{NO}_{3}^{-}$ of urine $(r=-0.7$ and -0.7$)$. These changes in the parameters of OMP and of NO metabolism are to some extent dependent on the activity of AOS. The decrease in the $\mathrm{NO}_{2}{ }^{-}$and $\mathrm{NO}_{3}{ }^{-}$content in plasma correlated with an increased GR activity of erythrocytes ( $r=-0.88 ;-0.87)$, and their content in urine, with an increased GSH content and catalase activity in serum $(r=-0.74$ and $-0.74 ;-0.82$ and -0.82$)$. Activation in liver of the spontaneous $\mathrm{PC}_{356} \mathrm{PC}_{370}$ formation affects the increase in the catalase activity of liver $(r=0.8 ; 0.83)$, of $\mathrm{PC}_{530}-$ on GSH content $(r=0.73)$, and of $\mathrm{PC}_{430}-$ on increasing of GR activity of erythrocytes $(r=0.75)$. We also found a correlation between a decreased activity of NOS in liver and increased activity of catalase in blood serum and liver $(r=-0.7 ;-0.69)$. We proved that a decrease in the $\mathrm{Fe}(\mathrm{II})$-induced $\mathrm{PC}_{530}$ level in serum has a high correlation with the growth of TBARS content in the blood $(r=-0.85)$.

Based on the obtained results we concluded that the studied derivatives of succinic acid in at the tested doses may disrupt the pro-/antioxidant balance primarily through inhibition of GPx. However, the organism tries to compensate the effects of $\beta$-PhEAOSAA metabolites by activation of catalase and GR that, to some extent, can prevent the damage of cellular structures by the free radicals or peroxides. The specific effect of the studied compounds is the inhibitory impact on the NOS of liver, by the severity of which $\beta$-PhEA-OSAA dominates its metabolites, $\beta$-PhESA and 2-HPhSA. Such direction of the compounds' impact against NOS in a certain way is reflected in the decrease of $\mathrm{NO}_{2}{ }^{-}$and $\mathrm{NO}_{3}{ }^{-}$content in plasma and urine. Under introduction of $\beta$-PhESA the content of NO metabolites decreased to a lesser extent than under $\beta$-PhEA-OSAA and 2-HPhSA that proved to have an expressed correlation between these indicators and the activity of NOS. In the liver under the $\beta$-PhEA-OSAA and $\beta$-PhESA impact the content of NO metabolites decreased slower than the activity of NOS, considering a possibility of their partial reduction due to an activation of compensatory mechanisms. The succinamides also cause a slowdown in urinary excretion of NO metabolites. We found that the reduction in the NO-NOS system activity is associated with the changes in the activity of GPx, catalase and GR.

We found that in the whole organism the derivatives of succinic acid cause high content of peroxida- tion products which are synchronized with intensification of the spontaneous OMP for $\beta$-PhEA-OSAA and 2-HPhSA, and for the latter compound also of the induced OMP. In liver the intensity of OMP under introduction of $\beta$-PhEA-OSAA and $\beta$-PhESA increases, but under the influence of 2-HPhSA, on the contrary, decreases, as the same direction of changes in the LPO parameters is seen under the action of $\beta$-PhEA-OSAA. In case of $\beta$-PhEA-OSAA we established a connection of the spontaneous $\mathrm{PC}_{530}$ formation with the intensity of LPO in blood, as well as the impact of these changes on the content of LPO products in liver. Under the $\beta$-PhEA-OSAA metabolites introduction the LPO intensity strongly depends on the level of the $\mathrm{Fe}(\mathrm{II})$-induced $\mathrm{PC}_{530}$ in blood serum.

The comparison of the succinamides effects showed that by the LPO intensity, $\beta$-PhEA-OSAA metabolites are more active than the compound itself. However, the spontaneous level of PC fractions in serum under $\beta$-PhEA-OSAA introduction exceeds the appropriate indicators under influence of its both metabolites, except for the liver where it is inferior to $\beta$-PhESA.

The activity of AOS and NO-NOS significantly influences the intensity of LPO and OMP, and at the same time, is dependent on their activity. Under $\beta$-PhEA-OSAA action we witnessed the well expressed interconnection between the reducing catalase, GPx, GST activity and LPO inhibition as well as increasing OMP intensity in liver and serum. Under $\beta$-PhESA influence the increase in GSH content, catalase and GR activity depends on the augmentation of the spontaneous level of the certain PC factions in liver, and the GPx inhibition, to some extent, affects the increase of the LPO rate in liver. In case of 2-HPhSA we registered the dependence of the imbalance in the catalase and GPx activity on the intensity of the spontaneous OMP. On the whole, under application of all studied compounds we found the relation between the decrease in the NO-NOS system activity and accumulation of the various PC fractions in liver and serum.

Thus, we concluded that the criteria for evaluation of potential adverse effects of the studied succinate-containing compounds on the oxidative status in subtoxic doses may include the increase in the spontaneous OMP and LPO intensity, reduction in the NO metabolites content and the GPx activity. 


\section{ПРО-/АНТИОКСИДАНТНІ РЕАКЦЇ̈ ТА МЕТАБОЛІЗМ ОКСИДУ АЗОТУ В УМОВАХ ПІДГОСТРОї ДІї ПОХІДНИХ БУРШТИНОВОї кИСЛОТИ}

\section{I. А. Палагіна}

ДУ «Інститут проблем ендокринної патології ім. В. Я. Данилевського НАМН України», Харків; e-mail: lab-tox@ukr.net

Похідні бурштинової кислоти $є$ активними сполуками, які реалізують свою біологічну дію шляхом впливу на про-/антиоксидантні процеси та енергетичний метаболізм. У роботі досліджено метаболізм оксиду азоту та реакції вільнорадикального пероксидного окислення протеїнів і ліпідів в організмі щурів за умов підгострої дії сполук з антидіабетичною активністю - похідного бурштинової кислоти та його метаболітів. Встановлено, що досліджені сполуки зумовлюють зміни інтенсивності протеїн- та ліпопероксидації в печінці та сироватці крові щурів, які взаємопов'язані зі змінами активності ключових антиоксидантних ензимів. Похідні бурштинової кислоти виявили інгібувальну дію на синтазу оксиду азоту, що позначалося на зниженні рівня нітрит- i нітрат-аніонів у печінці, плазмі крові та сечі, а також на змінах стану окислювальних процесів у печінці та сироватці крові. Зміни про-/антиоксидантних реакцій та гомеостазу оксиду азоту можуть бути критеріями оцінки біологічної дії сукцинатвмісних сполук.

К л ю ч о в і с ло в а: похідні бурштинової кислоти, біологічна дія, пероксидне окислення, оксид азоту.

\section{ПРО-/АНТИОКСИДАНТНЫЕ РЕАКЦИИ И МЕТАБОЛИЗМ ОКСИДА АЗОТА ПРИ ПОДОСТРОМ ВОЗДЕЙСТВИИ ПРОИЗВОДНЫХ ЯНТАРНОЙ КИСЛОТЫ}

\section{И. А. Палагина}

ГУ «Институт проблем эндокринной патологии им. В. Я. Данилевского НАМН Украины», Харьков; e-mail: lab-tox@ukr.net

Производные янтарной кислоты являются активными соединениями, которые реализуют свое биологическое действие путем влияния на про-/антиоксидантные процессы и энергетический метаболизм. В роботе исследованы метаболизм оксида азота и реакции свободнорадикального пероксидного окисления протеинов и липидов в организме крыс при подостром воздействии соединений с антидиабетической активностью - производного янтарной кислоты и его метаболитов. Установлено, что изученные соединения вызывают у крыс изменения интенсивности протеин- и липопероксидации в печени и сыворотке крови, взаимосвязанные с изменениями активности ключевых антиоксидантных энзимов. Производные янтарной кислоты оказывают ингибирующее действие на синтазу оксида азота, что проявляется в снижении уровня нитрит- и нитрат-анионов в печени, плазме крови и моче, а также изменениях состояния окислительных процессов в печени и сыворотке крови. Изменения про-/антиоксидантных реакций и гомеостаза оксида азота могут быть критериями оценки биологического действия сукцинатсодержащих соединений.

К л ю че в ы е с л о в а: производные янтарной кислоты, биологическое действие, пероксидное окисление, оксид азота.

\section{References}

1. Chekman IS, Gorchakova NA, Frantsuzova SB, Nagornaya EA. Metabolic and metabolitotropic drugs in the system of cardio- and organoprotection. Kiev: Poligrafplus, 2009. 155 p. (In Russian).

2. Galenko-Yaroshevskiy PA, Chekman IS, Gorchakova NA. Essays on the pharmacology of metabolic therapy drugs. M.: Medicina, 2001. 238 p. (In Russian).

3. Shakhmardanova SA, Gulevskaya ON, Khananashvili YaA, Zelenskaya AV, Nefedov DA, Galenko-Yaroshevskiy PA. Succinic and fumaric acid drugs for prevention and treatment of various diseases (review). Zhurn Fundam Med Biol. 2016; (3): 16-30. (In Russian).

4. Raketskaya EA, Chekman IS, Gorchakova NA. Yacton and mexicor influence on prooxidantantioxidant homeostasis and protein synthesis in the myocardium of rats in conditions of doxorubicin cardiomyopathy. Zaporozh Med Zhurn. 2015; 2(89): 25-27. (In Ukrainian). 
5. Yasnetsov VV, Prosvirova EP, Tsublova EG. Comperative study of the influence of succinatecontaining preparations on mitochondrial respiration in rat brain cells. Eksp Klin Farmakol. 2012; 75(7): 8-10. (In Russian).

6. Dorovskikh VA, Li ON, Simonova NV, Shtarberg MA, Dorovskikh VYu. Succinate containing drugs in the correction of lipid peroxidation processes of biomembranes induced by the heat exposure. Bull Physiol Pathol Respir. 2014; 53: 79-83. (In Russian).

7. Lukyanova LD. Mitochondrial signaling in hypoxia. Open J Endocr Metabol Dis. 2013; 3(2A): 20-32.

8. Saravanan R, Pari L. Effect of succinic acid monoethyl ester on hemoglobin glycation and tail tendon collagen properties in type 2 diabetic rats. Fundam Clin Pharmacol. 2008; 22(3): 291298.

9. Nebesnaya TYu, Gunina LM, Chekman IS. Study of quantum-pharmacological properties and protection of the spectrum of succinic acid pharmacological activity. Bull Probl Biol Med. 2009; 1: 101-107. (In Ukrainian).

10. Zarubina IV, Lukk MV, Shabanov PD. Antihypoxic and antioxidant effects of exogenous succinic acid and aminothiol succinate-containing antihypoxants. Bull Exp Biol Med. 2012; 153(3): 336-339. (In Russian).

11. Gorbenko NI, Poltorak VV. Molecular mechanisms of insulin secretion impairment in type 2 diabetes mellitus and possibility of its correction by succinic acid derivatives (review and own results). Endokrynologia. 2002; 7(2): 233-241. (In Ukrainian).

12. Naito Y, Lee M, Kato Y, Nagai R., Yonei Y. Oxidative stress markers (review). Anti-Aging Medicine. 2010;7(5):36-44.

13. Bian K, Doursout MF, Murad F. Vascular system: role of nitric oxide in cardiovascular diseases. J Clin Hypertens (Greenwich). 2008; 10(4): 304310.

14. Platser Z, Vidlakova M, Kupila L. Defenition of dienic conjugates and general hydroperoxides in biological samples. Czechoslovak Med Survey. 1970; 16(1): 30-34. (In Russian).

15. Asakawa T, Matsushite S. Colorings conditions of thiobarbituric acid test for detecting lipid hydroperoxides. Lipids. 1980; 15(3): 137-140.
16. Stalnaya ID, Garishvili TG. Method of definition of Malonic Aldehyd with the help of the thiobarbituric acid. In: Contemp. Methods in Biochemistry. Edited by Orekhovitch VN. M.: Medicina, 1977. P. 66-68. (In Russian).

17. Arutyunyan AV, Dubinina EE, Zybina NN. Methods of estimating the free-radical oxidation and anti-oxidant system of an organism. Method. Recomm. : appr. by Russ. Acad. Med. Sci. Sankt Petersburg: Foliant, 2000. 104 p. (In Russian).

18. Misheneva VS, Goriukhina TA. Presence of glutathione in normal and tumorous tissues of humans and animals. Vopr Onkol. 1968; 14(10): 46-49. (In Russian).

19. Ovsyannikova LM, Alyokhina SM, Drobinska OV. Biochemical and Biophysical methods of estimating disorders in oxidizing homeostasis in persons suffered from Chernobyl disaster. Method. Recomm. : appr. by Ministry of Health Care of Ukraine, Academy of Medical Sciences of Ukraine. Kiev, 1999. P. 7-9. (In Ukrainian).

20. Korolyuk MA, Ivanova LI, Mayorova IG, Tokarev VE. A method of determining catalase activity. Lab Delo. 1988; (1): 16-19. (In Russian).

21. Solodkov AP, Veremey IS, Osochuk SS, Scherbinin IU, Dedyun GV, Dubrovskaya AV. Photometric method of defining nitrites and nitrates in biological liquids (Manual): appr. by Ministry of Health Care of Belarus Rep. Vitebsk: [w/o publ.], 2001. 9 p. (In Russian).

22. Sumbayev VV, Yasinskaya IM. DDT effect on rat liver, lungs and brain nitric oxide synthase activity. Sovrem Probl Toksikol. 2000; (3): 3-7. (In Russian).

23. Gasparov VS, Degtyar VG. Definition of protein by its linkage to Kumassi Diamond light-blue G-250 dye. Biokhimiya. 1994; 59(6): 763-775. (In Russian).

24. Grimsrud PA, Xie H, Griffin TJ, Bernlohr DA. Oxidative stress and covalent modification of protein with bioactive aldehydes. $J$ Biol Chem. 2008; 283(32): 21837-21841.

25. Pyr Dit Ruys S, Bonzom JM, Frelon S. Benchmarking of protein carbonylation analysis in caenorhabditis elegans: specific considerations and general advice. Free Radic Biol Med. 2016; 99: 364-373. 
26. Kudria MY, Palagina IA, Mishenko TV, Ustenko NV, Pavlenko TA, Zhurakovskaya MV. Influence of phensuccinal and its metabolites on carbohydrate and energy metabolism at rats in the conditions of subchronic experiment. Probl Endocrin Patol. 2012; (4): 109-115. (In Russian).

27. Mayer B., ed. Nitric oxide. New York: Springer Science \& Business Media; 2012. 667 p.
28. Toledo JC Jr, Augusto O. Connecting the chemical and biological properties of nitric oxide. Chem Res Toxicol. 2012; 25(5): 975-989.

29. Horita S, Nakamura M, Shirai A, Yamazaki O, Satoh N, Suzuki M, Seki G. Regulatory roles of nitric oxide and angiotensin II on renal tubular transport. World J Nephrol. 2014; 3(4): 295-301.

Received 07.04.2017 